\title{
Modern Succession of the Outstanding Traditional Culture in Ideological and Political Education in Universities
}

\author{
Yiqiu Wang ${ }^{1, a}$, Shijie $\mathrm{Li}^{1, b}$ \\ ${ }^{(1}$ Zhao Tong University,Zhaotong city in Yunnan province,China,657000) \\ aemail, ${ }^{b}$ email
}

Keywords: Ideological and political education, Outstanding traditional culture, Modern succession

\begin{abstract}
The 5,000 thousand years' history of civilization development of China has accumulated rich spiritual treasure. The permeation of Chinese outstanding traditional culture in the ideological and political education in universities is conducive to the modern heritage of excellent culture. After giving the connotation of the Chinese excellent traditional culture, this paper expounds the significant functions of outstanding traditional culture in ideological and political education. The combination methods of the excellent traditional culture and the ideological and political education are analyzed to provide some references for the relative researchers.
\end{abstract}

\section{Connotation of Chinese Outstanding Traditional Culture}

Chinese traditional culture refers to the ideology and action of formation accumulated, speeded down, and still exist in the life and growth in nature influences on modern society China ancient culture in the long process of historical development. The generalized culture includes the material culture, the system culture and the thought culture which are formed in the form of objective. We usually say Chinese traditional culture is the narrow sense of culture, namely ideology and culture, it refers to the Chinese nation in the theoretical and non-theoretical multiplication in the formation of the national way of thinking, values, ethics, character, aesthetic taste, knowledge structure, behavior norms, customs and habits the form of existence and continuation of the sum and then influence the social and spiritual achievements with stable state of the. In essence, whether general or special, traditional culture has been internalized into the personality of the whole Chinese nation's cultural psychology and culture, and penetrate into the social politics and economy, especially in various fields of spiritual life, become the social development process, a powerful force even about people's ideology and daily behavior. Chinese traditional culture refers to the Chinese society in the long process of historical development and the accumulation dominates the overall characterization of most Chinese has positive impact on the value system, ideology, moral standards and norms of behavior. Chinese excellent traditional culture contains abundant connotation, which is one of the origins of modern civilization. In the course of five thousand years of development, the traditional culture Chinese highlights the characteristics of continuity in history has never stopped developing, it is more strain, there have been no Chinese traditional culture by foreign traditional culture or replace the phenomenon of conquest. The reason why the Chinese traditional culture has the characteristics of continuity is that it is influenced by the space factor and the precipitation time factor. In the context of the revival of traditional culture, it is of great significance to explore the influence of excellent traditional culture on Ideological and political education of students in universities.

\section{Significant Functions of Outstanding Traditional Culture in Ideological and Political Education}

Build Correct Thought. China's outstanding traditional culture heritage of the Chinese nation for thousands of years of history, in the process of development through continuous accumulation and precipitation gradually formed a distinctive feature, can be described as broad and profound. In the 
development of China's excellent traditional culture, we always pay more attention to the realization of people's world outlook, outlook on life and values. One of the major ways at the same time Chinese traditional theory of value realization is through the personality improvement to achieve continuous improvement, because after a certain personality development will show a colorful attitude. Confucianism requires people to pay attention to the promotion and cultivation of personality. In the excellent traditional culture of China, the pursuit of the ideal personality and the pursuit of the spiritual realm are all the more prominent in the world. Therefore, it is of great practical significance for college students to have a good idea of the traditional culture into the ideological and political education of college students in the new era. The spirit of constantly striving for self-improvement in Chinese traditional culture is a kind of psychological state and psychological quality which is needed by the modern society. It is beneficial to the cultivation of College Students' psychological quality. The basic connotation of socialist core values is the inheritance and development of Chinese excellent traditional culture. Therefore, Chinese traditional culture is an important ideological source of socialist core values, to cultivate and practice the socialist core values, ideological and moral strength to draw nutrition from the Chinese traditional culture, combined with the requirements of the times, to dig up the essence, and keep pace with the times, give it a new connotation of the times, to become foster excellent traditional culture the socialist core values of the rich fertile soil.

Strengthen Patriotic Consciousness. Historical practice has proved that China is a great country. The Chinese nation will certainly achieve its great rejuvenation. Patriotic expression of contemporary college students is in many aspects, including the love of the motherland, the culture of great mountains and rivers of the motherland love and love to the country and compatriots and so on, at the same time the core ideology of patriotism is china. As only the heart of compatriots and love of the motherland is able to make Chinese standing in the river of history, can be common in China to learn together, life and the development of labor, work together to create brilliant Chinese civilization development better. Expression of patriotism in Chinese outstanding traditional culture is the most appropriate, in the development of history, many patriotic martyrs with their precious lives explained this, made an important contribution to the development of Chinese. Especially the revolutionary martyrs, through the form of nationalism and maintain the unity, love the motherland and hatred, the patriotic spirit of play to the extreme, all the people should be proud of their spirit, should also be like them shoulder the important historical mission of realizing the great rejuvenation of our country, write a magnificent chapter in the future Chinese the development of the. At present, the majority of colleges and universities can use multimedia and other high-tech means to carry out ideological and political education, the traditional culture of sharing teaching resources of Ideological and political education by using network information communication technology smoothly, cannot do without the guidance of the scientific theory. The integration of Chinese traditional excellent culture and ideological and political education in universities needs the guidance of Marx's scientific theory.

Establish Harmonious Relationship. The Chinese nation has a long history and culture, excellent traditional culture by generations of Chinese people passing the torch, it is the ideological value of Chinese national spirit and emotion fully reflects the excellent Chinese traditional culture connotation is rich, has experienced thousands of years of evolution and sedimentation. The traditional culture has a wealth of features, the essence of China's outstanding ideological and cultural remains for the growth of Chinese children and learning to provide nutrients. There is no doubt that the ideological and political education in Contemporary Colleges and universities cannot be separated from the excellent traditional culture. Under the background of economic globalization, we should dig out the theoretical value of excellent traditional culture and apply it to our social life. Chinese culture is the Chinese nation inexhaustible power for life and growth in nature in unity we have a comprehensive understanding of traditional culture China, use of the excellent traditional culture of Ideological and political education, and maintain the national character can better reflect the spirit of the times, at the same time. For the majority of young college students, to accept the influence of the traditional culture, is conducive to improve their own quality and self-control, enhance their own culture, while enriching their spiritual connotation. On the cultivation of the ideal of life focus on the ideal personality China traditional culture, focusing on the development of 
self-perfection, emphasizing the unity of emotion and rational desire, provides a useful reference for the current ideological and political education of College students. The idea of harmony between man and nature in Chinese traditional culture embodies the pursuit of truth, goodness and beauty, and emphasizes the harmonious development of man, nature and society. Harmonious thought has become an important thought in Chinese traditional culture. It is of great significance for the construction of new interpersonal relationships and the promotion of social harmony.

\section{Modern Inheritance Models of Outstanding Traditional Culture in Ideological and Political Education in Universities}

Improve Class System. In the ideological and political education of college students, the main reason for the lack of traditional culture education is the lack of the overall planning of traditional culture education. To highlight the importance of traditional culture education. We must strengthen the overall planning and design of the system of traditional culture education in the ideological and political education, the initiative will be the excellent traditional cultural education of college students in the ideological and political education resources contained in Chinese traditional culture connotation is rich in Ideological and political education of College students. In the process of the overall planning, the emphasis should be placed on the strength of the traditional culture education into the teaching materials and the classroom. Some colleges and universities have made some attempts in the course of traditional culture, but the proportion of traditional cultural education in the ideological and political education of college students is still relatively small. So, to increase the strength of the excellent traditional cultural education in the ideological and political education, will traditional culture curriculum plan training courses of school personnel, increase the proportion of outstanding traditional culture education in the whole school curriculum system, such as the creation of historical, cultural and artistic traditions and other aspects of the curriculum, students are encouraged to the traditional culture elective credits. Chinese excellent traditional culture has a long history, it contains a very rich content of culture is the spirit of a nation, on behalf of a nation's value orientation. The work of Ideological and political education cannot do without the guidance of the excellent traditional culture, the value orientation of college students is affected by the bad social values to a certain extent, some young students' political consciousness, political and ideological beliefs blindly, and even the lack of social responsibility, integrity awareness and other undesirable phenomena. At present, it is necessary to take advantage of the favorable conditions of modern science and technology, to think about the way of the integration of traditional culture and ideological and political education, and to create a good campus environ

Deep Education Content. Chinese excellent traditional culture has rich connotation and profound meaning, can be fused in the top-level design, the work of Ideological and political education and the excellent traditional culture to create a strong cultural atmosphere of the traditional ideological and political education classroom. The teachers combine the classic values in the traditional culture with the ideological and political education in universities, and take the excellent traditional values as the breakthrough point to lead the students to establish the correct socialist core values. From the beginning of the freshmen, and actively carry out the integration of outstanding traditional value model of the ideological and political education, to guide the new understanding of the environment and adapt to the environment as soon as possible to identify their location in the university in the new environment, aware of their own has become a college student. At the same time, it is necessary for college freshmen to realize that in the new environment, they should put their own development into the collective environment, and keep the high spirits. In the teaching of specialized courses, the most effective way is to set up the teaching of professional history in the teaching of each specialty. Through the study of the history of professional education, to integrate traditional culture education in subject teaching, so that students have a more comprehensive and clear understanding of the history of the formation and development of the professional, so as to enhance the students' interest in professional learning, which is an important way to carry out professional culture of traditional education, enhance the students' professional tradition the spirit of the pursuit of culture and cultural 
pursuit. As the pulse of the nation and the spiritual home of the people, culture is the ideological value of the soul, and some scholars call it the national values and national wisdom. In the ideological and political education of college students to carry out the traditional culture education, it is necessary to dig out the value of excellent traditional culture, which needs to grasp the core concept of Chinese traditional culture.

Expand Teaching Approach. With the development of the times and the progress of science and technology, the development of the network to update the course of Ideological and political education in universities in the China mode. Therefore, traditional culture into the ideological and political course, related educators need to should use their own schools with the network environment, the ideological and political education of the students in a new way. Teachers in the course of the professor can be connected through the network to the latest combination of traditional culture and ideological and political teaching cases to students, but also the use of the network to form a local area network to allow students to learn into groups. Practical education is very important. An ancient history of the building and a piece of precious historical relics can stimulate the students' learning interest more than the traditional teaching theory, make them consciously to learn, to achieve a multiplier effect. The teacher can also carry out red culture research methods, forming the group, to further improve and research and practice of the students to participate in learning activities, so that college students can actively involve in activities, so that they receive the traditional education in a rich learning atmosphere, and constantly improve the idea of self-repair. The content of the network can be ignored in the course of the ideological and political class in some universities, such as the use of multimedia teaching and the sharing of network resources and other modern information technology means. Many students sleep in class. This reflects the college students from another aspect of the traditional culture and education of the current inheritance is dissatisfied. As the ideological and political teachers in universities, in the process of teaching should also understand students for rich media and network teaching interests, actively carry out and enhance the effectiveness of ideological and political theory course.

\section{Conclusion}

Chinese traditional culture is the accumulation of thousands of years of ancient civilization of the Chinese nation, which is the spiritual bond of the Chinese nation. Its rich connotation provides the extremely rich educational resources for the modern ideological and political education. We should improve class system, deep education content and expand teaching approach to combine the excellent traditional culture with ideological and political education in universities.

\section{References}

[1] Zhang Shishuai, On the Value and Teaching of Traditional Culture in College Students' Ideological and Political Education [J]. Journal of National Academy of Education Administration, 2015(8): 56-61.

[2] Du Peng, A Study of integrating the Chinese Excellent Traditional Culture into Ideological \& Political Education in Colleges \& Universities [J]. Journal of Henan University of Technology (Social Science), 2017, 13(2): 87-95.

[3] Wang Yiyou, The Value of Traditional Chinese Culture in College Students' Ideological and Political Education and Realization [J]. Journal of Heilongjiang College of Education, 2017, 36(2): 80-82.

[4] Kang Liyong, The Value and Realization of Chinese Excellent Traditional Culture in the Ideological and Political Education of College Students [J]. Future and Development, 2017(3): 107-109+118. 